\section{European biotechnology plans leave the Lords cold}

\section{London}

Plans by the European Commission for a substantial programme of biotechnology research have received only limited support from the UK House of Lords Select Committee on the European Communities. The conclusion of the committee's report, Biotechnology in the Community (HMSO, £9.30), published last week, endorses the British government's view that the proposed budget for the hightechnology Framework research programme is too large. The report says the biotechnology programme "may be over ambitious and could duplicate activities supported elsewhere in the community". It recommends that "an appropriate appraisal procedure which limits the agroindustrial pilot programme only to projects which are likely to show promise of economic viability and recongised the possibilities of similar developments being carried out elsewhere should, however, be agreed and adopted".

The report will lend weight to Britain's lone veto of the $£ 4,500$ million, five-year Framework programme. Britain has been calling for a scaled-down programme of no more than $£ 3,000$ million, and has called current Community research projects "unfocused and poorly monitored". The Commission had been hoping that
Britain would agree to the research programme before the European Economic Community (EEC) summit in Brussels at the end of this month. Officials say that before the British general election, the government had been making "friendly noises", and the Belgians, who chair the EEC until the end of the month, are anxious to resolve the deadlock during their term.

Giving evidence before the Lords' committee, the government chemist, $\mathrm{Dr}$ R. Coleman, said that the Department of Trade and Industry (DTI) considered the Commission's proposal to spend 350 million ECU (European currency units; 1 ecu $=£ 0.7$ ) on agro-industrial development, agro-food research, agricultural research and biotechnology research was "significantly more than is justified". He suggested a figure of no more than $100 \mathrm{ECU}$ for the whole package. The Ministry of Agriculture, Fisheries and Food proposed a limit of 20 million ECU for a biotechnology programme "if it contained significant industrial input".

The Agricultural and Food Research Council, which in 1985-86 spent £20.5 million on biotechnology research, is predictably enthusiastic about the programme and the proposed levels of funding.
Simon Hadlington London

To the surprise of all involved, the crossexamination process in the tissue plasminogen activator (TPA) patent case in London's High Court (see Nature 327, 450 \& 546 ; 1987) finished in less than two weeks. By the middle of this week, the closing arguments from the lawyers representing both Genentech, the US biotechnology company that holds British patents, and Wellcome, the UK pharmaceutical company that is challenging them, will

Wellcome is trying to establish that the procedures used by Genentech's scientists to clone and express the DNA for TPA were 'obvious' at the time and therefore that the patents are invalid. Genentech, understandably, maintains that the techniques were not obvious in 1982 . One of the problems at the time was how to isolate from a complex mixture of many different DNA molecules one that is present in very low abundance. Genentech scientists solved the problem for TPA by 'oligonucleotide hybridization'.

The obviousness of this and other steps in the procedure used by Genentech became the subject of close examination during the first two weeks of the case. The

\section{Cross-examination ends} have been heard.

\section{Awards out of the blue \\ Washington}

THE first emotion experienced by winners of a MacArthur Fellowship seems to be disbelief. The reaction of Eric Lander, one of 32 winners of this year's awards* announced last week, is typical. Lander, a fellow at the Whitehead Institute and faculty member at Harvard University Graduate School of Business Administration, arrived home with his wife to find a message on his answering machine informing him he had won the fellowship worth $\$ 205,000$ over five years. Only after playing the tape a second time did Lander decide that the news might really be true.

The MacArthur Fellowship is unusual. Fellows neither apply for their awards, nor are they required to meet any performance standards to justify them. The programme is intended to give talented individuals an opportunity to be creative.

This is the sixth year of the awards programme. Some 100 nominators propose candidates to a 15-member selection committee, with final approval coming from the Foundation's Board of Directors. The size of the awards is based on the age of the recipient, plus an upward adjustment to take into account the newly taxable status of the award.

Winners have been chosen from a wide selection of academic and social interests. Superstring theorists seemed to have captured the imagination of this year's selection committee, with three of the four physicists winning awards working on strings.

Lander, whose research has been on mapping complex genetic traits, says he regards the award as "a very special pat on the back", adding that it will encourage him to "follow his nose" and not worry where his research will ultimately lead. Another winner, Ira Herskowitz, head of the division of genetics at the University of California, San Francisco, agrees the award is especially nice, because it rewards self-starters.

Joseph Palca concerns a substance that had already been isolated and, to some extent, characterized by conventional techniques. The question, therefore, is not so much whether a natural substance can be patented but whether its recombinant DNA forms and their production can be.

If Genentech wins the case the company less likely to have to fight the battle over again in too many countries, of which Japan may well be the first. If it loses it other than on a technicality of UK law, a series of battles seems certain.

Judgement is expected in mid-July. But if the judge needs more time to get to grips with molecular biology, the summer recess may delay a decision until October.

Peter Newmark
*Walter Abish, 55, writer; Robert Axelrod, 44, political scientist; Robert Coleman, 32, mathematician; Douglas Crase, 42, poet; Daniel Friedan, 38, physicist; David Gross, 46, physicist; Ira Herskowitz, 40 , biologist; Irving Howe. 67, writer; Wesley Jacobs, Jr, 31, rural planner; Peter Jeffery, 33, musicologist Horace Freeland Judson, 56, journalist; Stuart Kauffman, 47, biologist; Richard Kenney, 38, poet; Eric Lander, 30, mathematician; Michael Malin, 37 , geologist; Deborah Meier, 56, school teacher; Arnaldo Momigliano, 78, historian; David Mumford, 50, mathematician; Tina Rosenberg, 27, journalist; David Rumelhart, 45, psychologist; Robert Sapolsky, 30, endocrinologist; Meyer Schapiro, 82 , art historian; Jon Schwarz, 45, physicist; Jon Seger, 40, biologist: Stephen Shenker, 34, physicist; David Shulman, 38, philologist; Muriel Snowden, 70 , community organizer; Mark Strand, 53, poet; May Swenson, 68, poet; Huynh Sanh Thong, 60, translator and editor; William Julius Wilson, 51, sociologist; Richard Wrangham, 38, ethologist. 